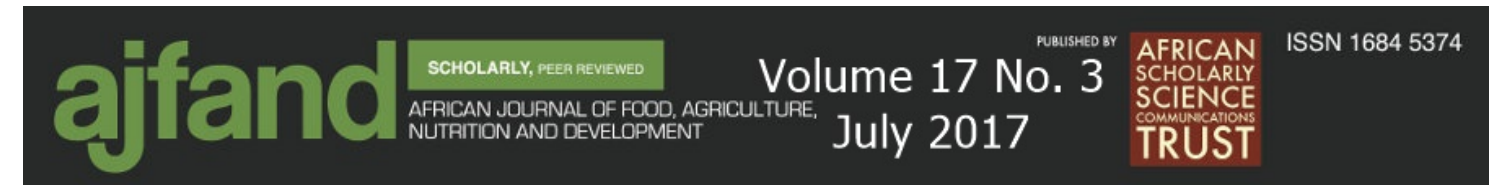

Afr. J. Food Agric. Nutr. Dev. 2017; 17(3): 12280-12294

DOI: 10.18697/ajfand.79.16285

\title{
CLIMATE SMART CROPS FOR FOOD AND NUTRITIONAL SECURITY FOR SEMI-ARID ZONES OF ZIMBABWE ${ }^{\mathrm{a}}$
}

$$
\text { Jiri }{ }^{1,2 *} \text {, Mafongoya } \mathrm{PL}^{1} \text { and } P \text { Chivenge }{ }^{1,3}
$$

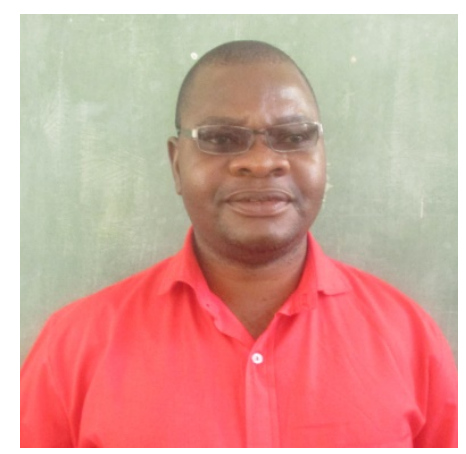

\section{Obert Jiri}

*Corresponding authors email: obertjiri@yahoo.co.uk

${ }^{1}$ School of Agricultural, Earth and Environmental Sciences, University of KwaZuluNatal, Private Bag X01, Scottsville, Pietermaritzburg, 3209, South Africa

${ }^{2}$ University of Zimbabwe, Faculty of Agriculture, P. O. Box MP167, Mt Pleasant, Harare, Zimbabwe

${ }^{3}$ International Crops Research Institute for the Semi-Arid Tropics, P O Box 776, Bulawayo, Zimbabwe

\footnotetext{
${ }^{a}$ Parts of this paper are based on a paper presented at the University of KwaZulu-Natal Research Day (2016) and published [39]
} 


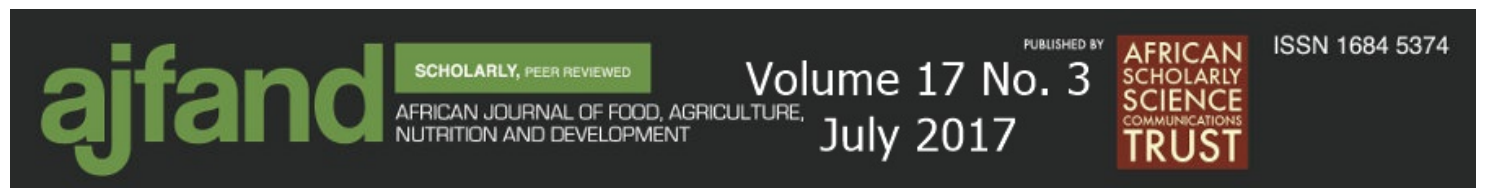

\begin{abstract}
Southern Africa smallholder farmers continue to be the most affected by the challenges of climate change and variability. The variability of climate demands the use of a variety of agronomic strategies and crop choices. Traditional drought tolerant cereal crops such as sorghum and millets are often chosen when drought seasons are anticipated. However, there are certain crops, originating elsewhere, that could help the smallholder farmers increase diversity of crops that can be grown in changed climates. Trials were conducted to test a basket of known and introduced climate smart crops in the field. The cereal crops tested were maize, sorghum, pearl and finger millet, and legumes: tepary bean (Phaseolus acutifolias), cowpea (Vigna unguiculata), Bambara nut (Vigna subterranea), groundnut (Arachis hypogaea) and pigeon pea (Cajanus cajan. A second experiment was conducted to determine the effects of inorganic fertilizer and rhizobium inoculation on the growth and grain yield of field grown tepary bean. Both experiments were laid out in a randomized complete block design with three replications. Due to drought conditions during the growing season, cereal crops could not produce grain yield, as there was no grain filling. Despite this, cereal biomass was $5 \mathrm{t} \mathrm{ha}{ }^{-1}$ for maize, followed by sorghum $\left(1.3 \mathrm{tha}^{-1}\right)$ and millet $\left(1.2 \mathrm{tha}^{-1}\right)$. Legume crops produced grain with cowpea yielding $568.1 \mathrm{~kg} \mathrm{ha}^{-1}$ of grain, followed by tepary bean $\left(245.9 \mathrm{~kg} \mathrm{ha}^{-1}\right)$ and common bean $\left(227 \mathrm{~kg} \mathrm{ha}^{-1}\right)$. This is important for food, nutrition and health security of smallholder communities. Tepary bean inoculated with rhizobium and had fertilizer applied produced higher grain yield than those without fertilizer or rhizobium inoculant $(\mathrm{P} \leq 0.05)$. In conclusion, resource poor farmers, affected by drought effects of climate change, can adopt both cereals and legumes climate smart crops, in order to create food and nutritional security. This is crucial for food and nutritional security of vulnerable households affected by climate change and variability.
\end{abstract}

Key words: tepary bean, climate smart crop, drought, smallholder farmers 


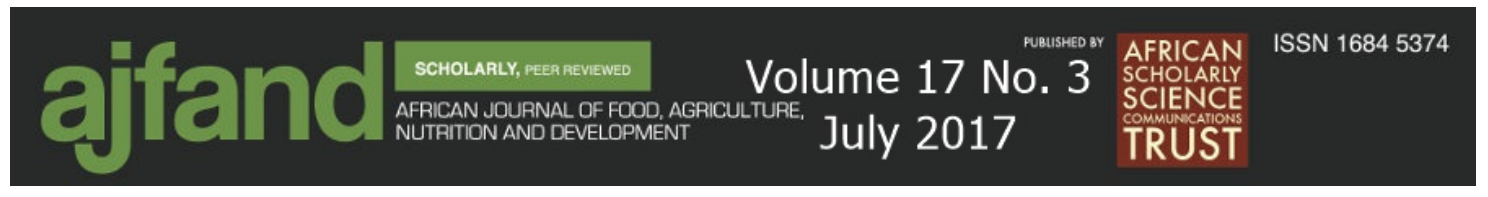

\section{INTRODUCTION}

Cereals are the most important sources of food and cereal-based foods are a major source of energy, protein, vitamin B complex and minerals for the world population [1]. Generally, cereals are cheap to produce, easily stored and transported, and do not deteriorate readily if kept dry. Over $50 \%$ of the world's cereal is produced in developing countries [2]. While cereal grains are rich in energy, they lack other essential nutrients and minerals. However, small grains are more nutritious than maize; for instance, pearl millet is rich in iron and zinc. Cereal grains are deficient in vitamin A and its metabolic precursor, beta-carotene, except for yellow maize. Additionally, they are deficient in vitamin $\mathrm{C}$ and vitamin B12. In most western countries, these vitamin shortcomings are generally of little consequence since the average diet is not excessively dependent upon grains and is usually varied and contains meat (a good source of vitamin B12), dairy products (a source of vitamins B12 and A), and fresh fruits and vegetables (a good source of vitamin $\mathrm{C}$ and beta-carotene) [3]. However, in some countries of Southern Asia, Central America, the Far East and Africa, cereal consumption can comprise as much as $80 \%$ of the total caloric intake, and in at least half of the countries of the world, bread provides more than $50 \%$ of the total caloric intake. In countries where cereal grains comprise the bulk of the dietary intake, vitamin, mineral and nutritional deficiencies are common [4].

The inclusion of legumes in the diet is important in controlling and preventing various metabolic diseases such as colon cancer, diabetes mellitus and coronary heart disease [5]. Legumes are the source of slow release dietary fibre (carbohydrates) and are rich in proteins $(18-25 \%)$ [5]. In Africa, legumes are the cheapest sources of supplementary proteins, besides being sources of minerals and vitamins. Leguminous grain is an important food source used to provide dietary protein and energy requirements. Leguminous grains have high dietary fibre content and low lipid, with emerging evidence emphasizing the importance of legume grain as carriers of polyphenols, saponins, oxalates, lectins, phytosterols and enzyme inhibitors. Further evidence also suggests the importance of pulses in human health, particularly in the prevention of coronary heart disease and diabetes [6].

Lately, grain legumes have come out of the shadows in research and extension because of their highly valued and multiple benefits for the farmer and the farming systems across the developing world [1]. For semi-arid regions in particular, inadequate and highly variable rainfall and short growing periods limit yield potential and create a risky primary production environment. Evidence from the Intergovernmental Panel on Climate Change (IPCC) is now overwhelmingly convincing that climate change poses one of the greatest challenges to agriculture and food security, especially in subSaharan Africa [7]. This is because the region is widely recognized as one of the most vulnerable in the world due to poor adaptive capacity, which is linked to acute poverty levels and poor infrastructure and high dependence of rainfed agriculture [8]. Among the most significant impacts of climate change is the potential increase of food insecurity and malnutrition. Projections suggest that the number of people at risk of hunger will increase by $10-20 \%$ by 2050 due to climate change, with $65 \%$ of this population in sub-Saharan Africa [9]. The number of malnourished children could 


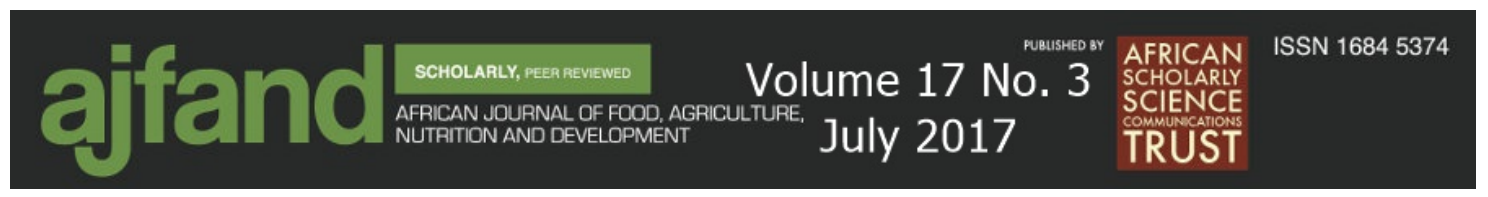

increase by up to $21 \%$ (24 million children), with the majority being in Africa [10]. These negative impacts of climate change and variability are presenting new challenges to the majority of smallholder farmers in the absence of appropriate response measures, hence the need to address the challenges. Food and nutrition strategies that bring cobenefits in terms of enhanced production of and access to food should be explored and tested. Focusing exclusively on increasing agricultural production is too short-sighted in the context of sustainable food and nutrition security under climate change because producing more food does not necessarily lead to better access to food or to improved nutritional status of those who need it most [11]. Adaptation is increasingly seen as an inevitable answer to the challenges posed by climate change [12]. Diversification of crops including new crop types and cultivars is one adaptation strategy that has been identified as a potential farm level response to climate change and variability [13]. Integration of $\mathrm{N}_{2}$-fixing legumes and other high value crops within smallholder farming systems has been identified as one of the climate change coping strategies to improve food and nutrition security. The potential for grain legumes as a food resource and for soil fertility replenishment has been widely researched [14]. Drought tolerant crops and high protein leguminous crops that include tepary bean (Phaseolus acutifolius) have over the years been largely ignored and neglected by research as minor crops. Such drought tolerant and leguminous crops have the potential to provide greater resilience to cope with the climate change challenge. Current global debates on climate change adaptation options for smallholder farmers need also to consider benefits for human nutrition [14]. Traditional crops such as small grains could be a strategy for reducing micronutrient deficiencies in humans [15]. Finger millet and sorghum contain high content of minerals and vitamins [16]. Changes in climatic conditions have already affected the production of some staple crops. Maize (Zea mays L.), the staple food of Zimbabwe, is the most widespread grain crop grown under rainfed conditions in the smallholder cropping systems. As such, food security in Zimbabwe is generally defined in terms of maize but average maize yields remain low $\left(<0.5 \mathrm{t} \mathrm{ha}^{-1}\right)$ and continue to decline, thus threatening household food security [17]; yet, in terms of nutritional importance, maize makes up $49.5 \%$ of the daily calorie intake in the country. However, cereal grain alone does not provide enough nutritional value. Grain legumes complement household dietary requirements since they have high protein levels [6]. Physiologically, it is not only the quantity of food but also its quality and combination into a varied and balanced diet, which is crucial [18].

The human race is faced with many issues related to the need for nutritious and adequate amounts of food. According to Greenfingers [19], there is no other food which has a more health-supportive nutrient profile than beans. This is because beans contain nearly equal amounts of protein and fibre, which is a unique combination that is rarely found in other plant foods. This combination together with the antioxidant content of beans has proved to be a powerful weapon against today's common diseases. However, tepary beans have been noted to be better than all other bean crops. Because of the high fiber content, tepary beans have the lowest glycemic index (the rate at which a type of food raises blood sugar levels) compared to other cultivars of beans [20]. Studies in the United States and Mexico suggest the importance of lectin toxins and other compounds from tepary beans in chemotherapy, halting the growth of cancer [21]. Furthermore, recent studies from the same region suggest that tepary beans are 


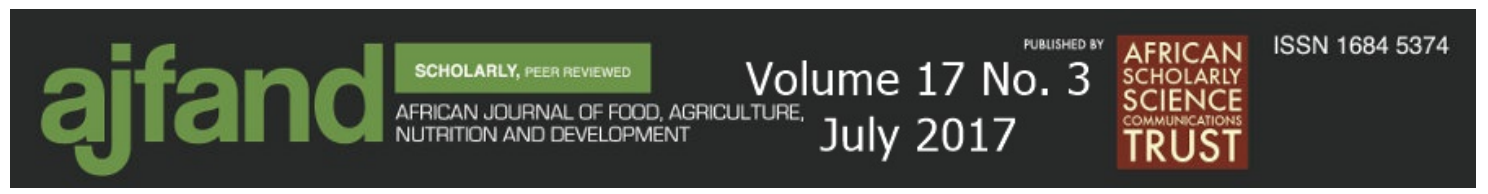

useful for treating cancer, and they could be ten times more effective than chemotherapy [21]. Tepary bean seeds were shown to contain at least two different groups of bioactive proteins with dissimilar effects on cancer cells. The lectins in tepary beans exhibited an anti-proliferative effect on non-transformed cells and on some cancer cells [22].

There is the potential for the use of drought-tolerant legumes, in combination with cereal crops in agriculture to provide adequate food and nutrition security. Such crop choices should be sustainable, resilient and of practical solutions to challenges facing smallholder farmers affected by drought due to climate change and variability. Consequently, the objective of this study was to test the agronomic performance of a group of commonly grown cereal crops including maize, sorghum, pearl and finger millet, and a group of legumes, cowpea (Vigna unguiculata), bambara nut (Vigna subterranea), groundnut (Arachis hypogaea) and pigeon pea (Cajanus cajan) and a newly introduced legume crop, tepary beans (Phaseolus acutifolias) as climate smart crops for production in smallholder communities affected by climate change and variability.

\section{MATERIALS AND METHODS}

The research was conducted at Makoholi Research Station in Masvingo Province, Zimbabwe $\left(19.5^{\circ} \mathrm{S}, 30.5^{\circ} \mathrm{E}\right)$ in the $2014 / 15$ agricultural season. Commonly grown legumes: cowpea, bambara nut, groundnut as well as introduced legumes, pigeon pea and tepary bean were tested. Cereal crops, maize, sorghum, pearl millet and finger millet, were also grown. All the crops were planted on January 19, 2015. The crops were fertilized at the known recommended rates for the area. Compound D fertilizer was applied at a rate of $150 \mathrm{~kg} \mathrm{ha}^{-1}$ before planting in the respective sub plots. Ammonium nitrate was applied at a rate of $100 \mathrm{~kg} \mathrm{ha}^{-1}$ at flowering/tasseling.

A separate experiment was conducted at the Crop Science Department, University of Zimbabwe, where tepary beans was grown with the following treatments: Basal fertilizer only (compound D fertilizer - 7:14:7 - N: P: K); Top dressing (Ammonium Nitrate $-34.5 \% \mathrm{~N}$ ) only; Rhizobium only; Rhizobium + top dressing; Basal fertilizer + top dressing; and a control with no fertilizer or inoculant.

The experimental design for both trials was a randomized complete block design, where experimental units were randomly assigned to treatments.

\section{METHODOLOGY}

At both experimental sites, a disc plough (3 disc plough manufactured by John Deere, Harare, Zimbabwe) was used to plough and disc the land. Planting was done by hand using a pre-marked wire cable at a spacing of $0.45 \mathrm{~m}$ between rows and $0.05 \mathrm{~m}$ within rows, with row length of $6 \mathrm{~m}$, for legume crops. Inter-row spacing of $0.90 \mathrm{~m}$ and intrarow spacing of $0.30 \mathrm{~m}$ was used for maize. Small grain cereal crops were planted at $0.90 \mathrm{~m}$ inter-row and broadcasted in-row. The legumes were hand-planted with four seeds planting hole and thinned after emergence to two plants per stand after 2 weeks. 


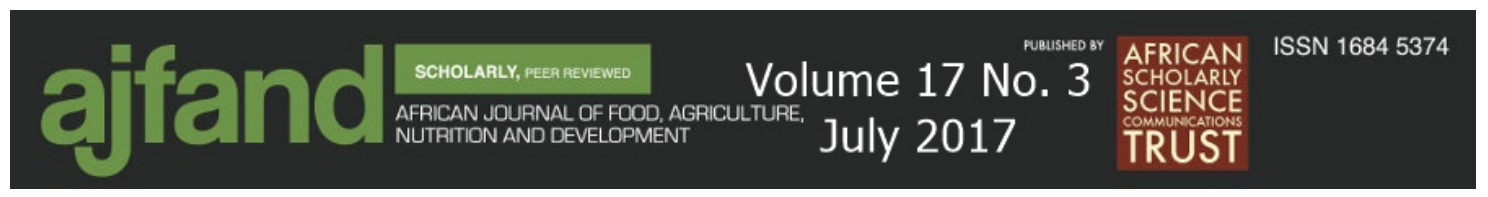

For the rhizobium treatments, sugar was dissolved in $250 \mathrm{ml}$ of water and mixed with the inoculant and applied to 20 grams of seeds, which were sown immediately. Manual (hand hoe) weed control methods were used throughout the season to keep the crops weed free. Agronomic and yield data were collected during plant growth and at crop maturity, respectively.

\section{Data analysis}

Data were analyzed using the statistical package $\mathrm{R}$ and Genstat 14. Treatment significant differences were declared at $\mathrm{P} \leq 0.05$.

\section{RESULTS}

\section{Season rainfall characteristics}

At Makoholi Research Station, total precipitation for the 2014/2015 growing season, December through May, was below normal. (Figure 1). Overall, the station had 115 $\mathrm{mm}$ of rainfall, which was $28.75 \%$ of the normal seasonal average $(400 \mathrm{~mm})$. During the six-month period, all the months had below normal rainfall. The most damaging aspect of the rainfall pattern occurred during the month of January. Precipitation in January $(15 \mathrm{~mm})$ was erratic and below half of the monthly normal (Figure 1).

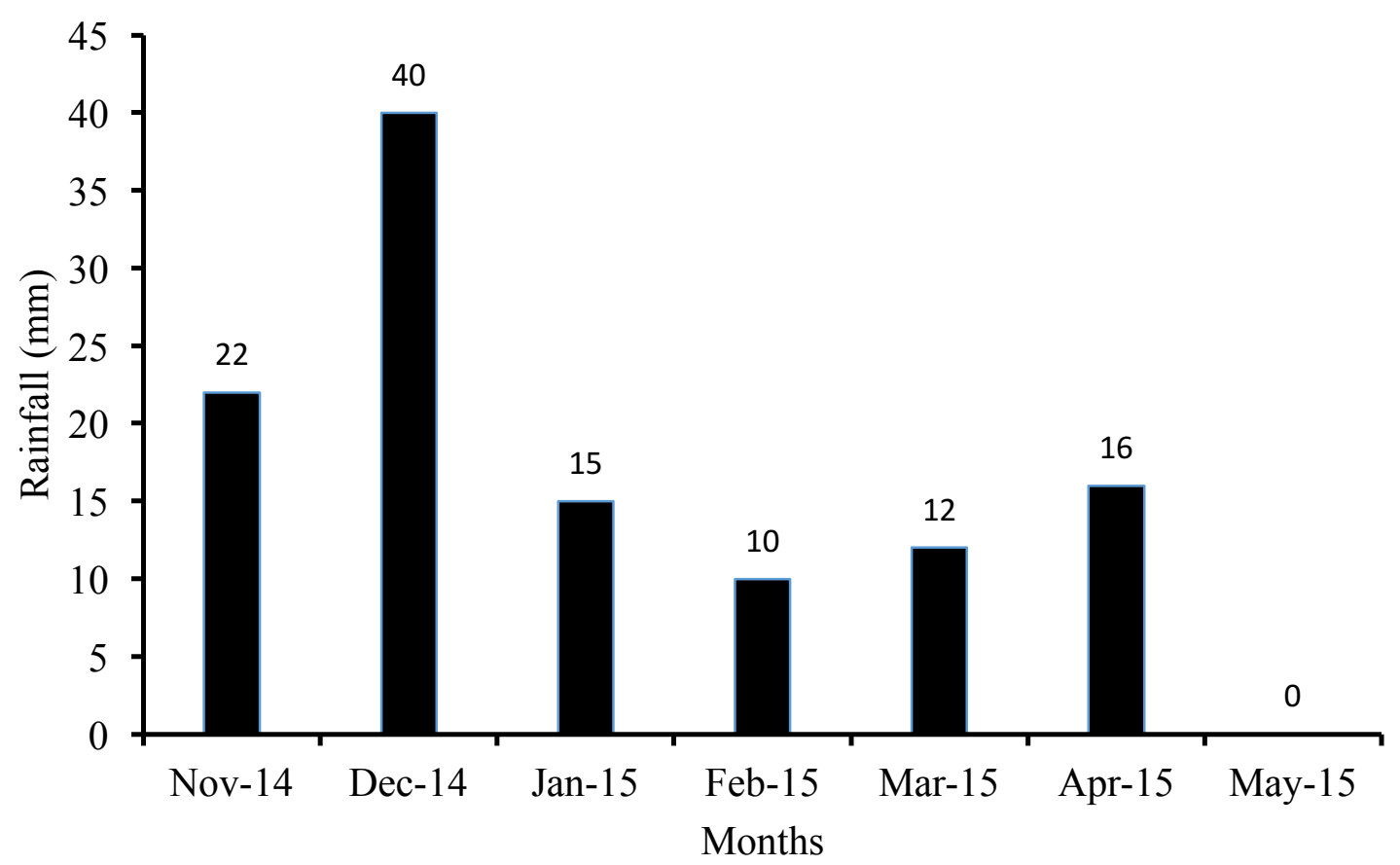

Figure 1: Rainfall data at Makoholi (2014/15 season) (Source: Makoholi Research Station rainfall records)

\section{Cereal and legume growth and yield}

Due to the low seasonal rainfall (115 mm seasonal total; Figure 1) and lack of moisture at tasseling and flowering, cereal crops at Makoholi failed to produce grain despite 


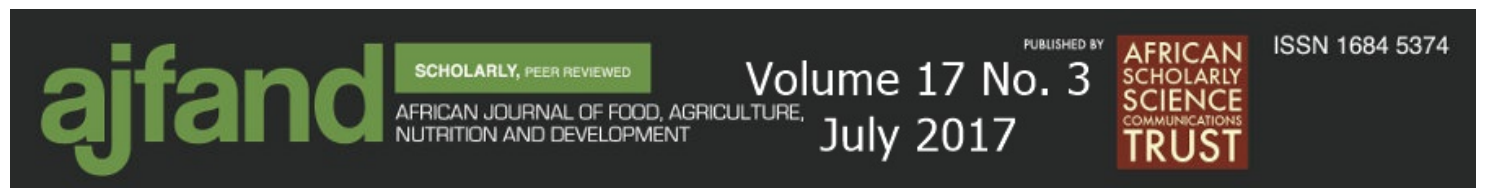

producing biomass (Table 1). Biomass production by the cereal crops was in the order: maize $>$ sorghum $=$ pearl millet $>$ finger millet. There was a significant statistical difference in maize biomass yield compared with all other crops $(\mathrm{P} \leq 0.05)$, although there was no significant difference in biomass yield between pearl millet and finger millet (Table 1). Sorghum was eaten by birds, as it was an easy source of feed, because of its larger grain. The other cereal crops, pearl millet and finger millet, were also eaten by birds. There was no grain harvest owing to lack of grain filling resulting from drought conditions. However, the little amount of grain that was produced was eaten by birds and could not be harvested. The low rainfall in the months of January and February, when most plants flower, pollinate, produce grain and fill, affected grain filling. Moisture stress during this critical growth period was a major factor contributing to the lack of yields by the cereal crops.

The legume crops were able to grow and produce biomass and some legumes produced grain yield (Table 2). Cowpea produced the highest grain yield $\left(568.1 \mathrm{~kg} \mathrm{ha}^{-1}\right)$ followed by tepary bean and common bean. Tepary bean and groundnut were the earliest to flower. Bambara nut, pigeon pea and groundnut were not able to produce grain for lack of rainfall (Table 2; Figure 1).

\section{Tepary bean yield}

In the second experiment, there were significant differences $(\mathrm{P} \leq 0.05)$ between yields of tepary bean with inorganic fertilizer treatments and those without fertilizer treatment. The highest grain yield was recorded for the treatment with basal fertilizer + top dressing. However, this was not significantly different from the treatment which had rhizobium + top dressing and the one with top dressing only and rhizobium only (Figure 2). The yield of tepary beans without fertilizer or inoculant was the least. 

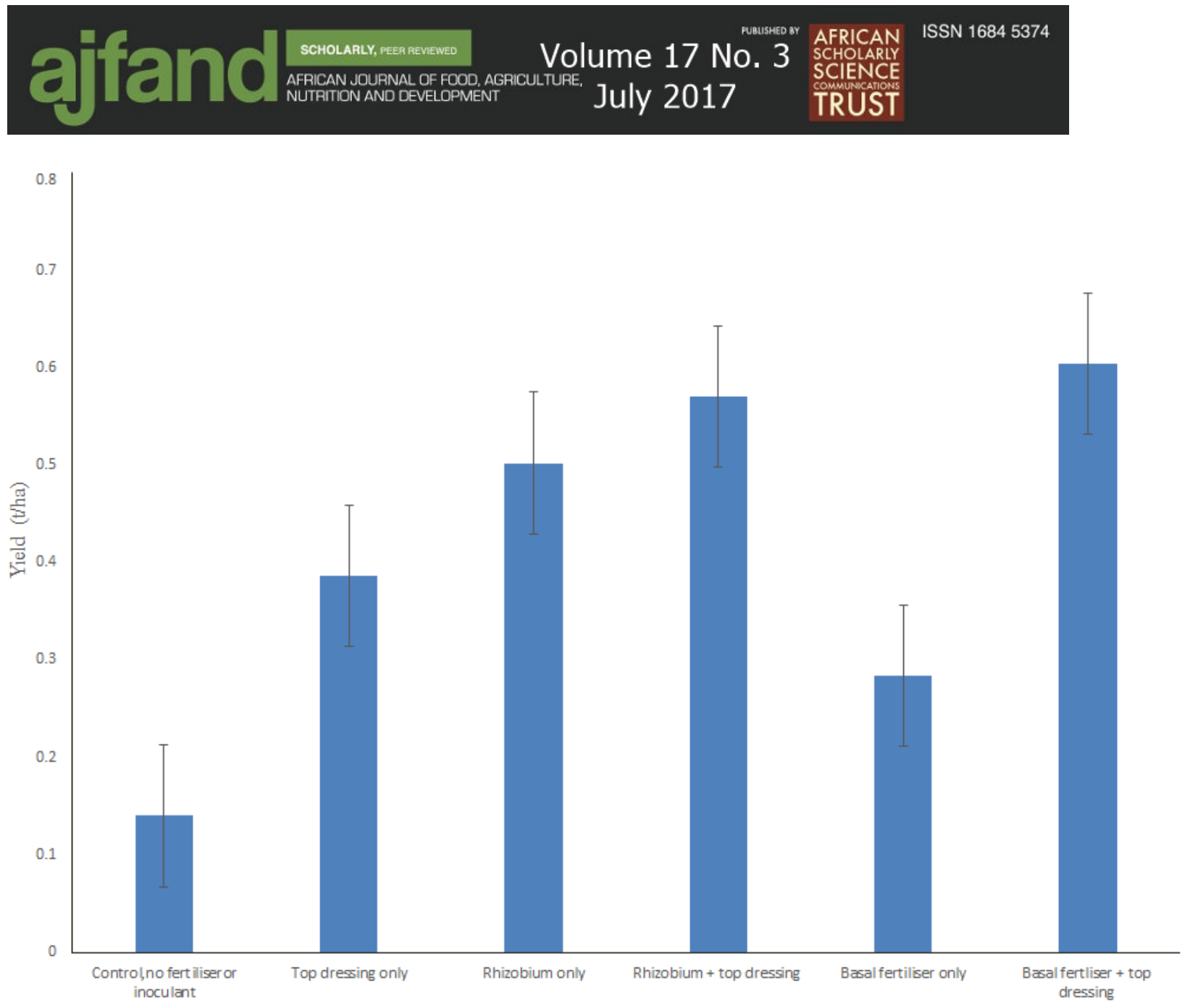

Figure 2: Tepary bean grain yield under various treatments

\section{DISCUSSION}

\section{Cereal crop yields}

The failure of cereal crops under the drought conditions at Makoholi (Figure 1) can be explained as adaptation failure. In the third assessment report, the IPCC defined such inappropriate outcomes as maladaptation. Specifically, the IPCC defined maladaptation as "any changes in natural or human systems that inadvertently increase vulnerability to climatic stimuli; an adaptation that does not succeed in reducing vulnerability but increases it instead" [23]. As adaptation outcomes traverse spatial and temporal boundaries they may become less relevant, ineffective or even inappropriate [24]. Even more drought-tolerant small-grain cereal crops could not produce any grain yield. This implies, that with increased drought conditions, cereal crops could become a less climate smart option for such areas.

It is important to note that birds preferred to feed on sorghum grain compared to pearl millet and finger millet grains. This may mean that if sorghum is adopted as a climatesmart crop, it would be less adaptable to the environment compared to pearl millet and finger millet. A similar observation was made in Kenya where sorghum was eaten by birds before it could be harvested [25]. 


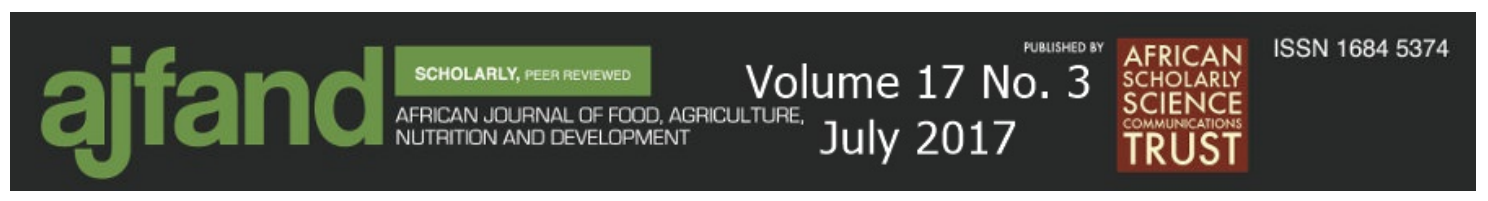

The herbage produced by the cereal crops could also become important in the mixed farming systems commonly practiced by smallholder farmers. Therefore, even when no grain is produced, the stover would still be important as livestock feed [26].

\section{Legume growth and yield}

Despite the low rainfall at Makoholi, and the late planting of the crops, legume crops were able to grow and some produced good yields (Table 2). Thus, with a short growing period, in the growing season and some residual soil moisture, it is possible to successfully grow most legume crops. This emphasizes the resilience of legume crops as key climate-smart crops that can fit into a short growing period in the growing season $[17,27]$. The climate change challenge and low soil fertility are major abiotic limitations to crop production, particularly for legume crops that are cultivated as escape crops and usually on marginal lands. Research has, however, placed legume crops to improve genetic adaptation to drought [28]. This could prove to be a major breakthrough in combating devastating effects of climate induced hunger and malnutrition, particularly in hard-hit areas of southern Africa [29].

The fact that groundnut, bambara nut and pigeon pea did not produce grain yield does not mean maladaptation of these crops. As indicated with cereal stover, the legume stover would also be important for livestock feed in the mixed farming systems that the smallholder farmers practice [26].

It is also known that these crops are some of the most drought tolerant crops in Africa [5]. There would be need to evaluate response of short duration varieties of these known climate smart crops in drought prone areas. This is important as farmers diversify crops as a coping strategy to climate change and variability [30]. Important legumes for smallholder farmers in southern Africa are bambara nut (Vigna subterranea (L.) Verdc.), common bean (Phaseolus vulgaris L.), cowpea (Vigna unguiculata (L.) Walp.), pigeon pea (Cajanus cajan (L.) Millsp.), groundnut (Arachis hypogaea L.) and tepary bean (Phaseolus acutifolius (A. Gray)), among other few legumes. The majority of these pulses are already being grown worldwide [5].

\section{Complementarity of cereal and legume grain for human nutrition}

Legumes are a cost-effective option for improving diets of low-income consumers who cannot easily afford other sources of protein [20]. This generates substantial benefits to the well-being of smallholder farm families. With many of the poorest countries deriving $10-20 \%$ or more of their total dietary protein from grain legumes, the importance of low-resource legumes cannot be overemphasized [5]. Cereal diets, such as maize-based diets in eastern and southern Africa, are low in lysine content relative to human amino acid balance. Legumes are superior sources of lysine, and increase the biological value of the combined protein. The current WHO-endorsed index for protein quality is the protein digestibility-corrected amino acid score (PDCAAS), which estimates the true value of dietary protein. Experts recommend that foodstuffs of at least $70 \%$ PDCAAS should be consumed [5]. Cereals have a low PDCAAS value of about $35 \%$, indicating their low protein quality when consumed in isolation, while a cereal-legume combination in the proportions of 70/30 (weight/weight) can usually reach or exceed this PDCAAS threshold $[5,18]$. Thus, even in countries where a cereal 


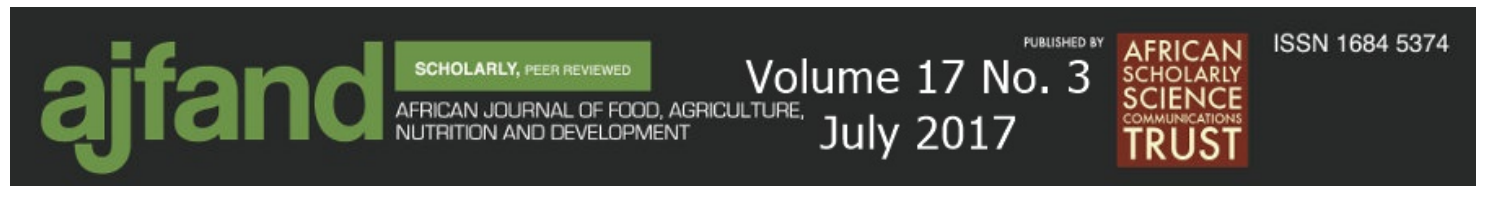

is the dominant source of protein, every gram of legume protein potentiates another gram of cereal protein. Legume proteins are rich in globulins and albumins and generally have isoelectric points of 4.2 to 4.4 [6]. These protein fractions are rich in lysine and other essential amino acids but generally low in sulfur containing amino acids; therefore, they complement protein quality of cereal-based foods [31].

Other health benefits of legumes include enhanced iron concentration in beans [32]. Grain legumes exhibit low glycemic index, thus reducing the risk of obesity and diabetes [5]. A bean diet, with exercise, was shown to decrease typical changes in weight gain, glycemia and lipid profile [32]. The low oil content in beans means that their consumption would have positive effects on colon and breast cancer [32], and cardiovascular disease. Preliminary tests with HIV/AIDS victims fed grain legumes shows an increase in cell counts of CD4 cells, a primary element of the immune system [5]. This may imply further importance of beans in diets.

\section{Growth, yield and importance of tepary bean, a climate smart crop option}

The high tepary bean yield obtained with fertilizer application contradicts results from Kenya where nitrogenous fertilizer did not have any significant effect on the yield of tepary bean [33]. This might mean that the effects of the rhizobium and basal fertilizer are the same if combined with ammonium nitrate. Basal fertilizer provides the plant with starter nutrients that are needed for early growth. However, according to Gary [28], phosphorus does not increase grain yield. The nutrient may have played an indirect role of promoting a good root network, which enabled the crop to absorb nutrients efficiently. Biological fixation of nitrogen by rhizobium contributes large amounts of plant usable nitrogen to the soil nitrogen pool [14]. This plant usable nitrogen might have an effect in the early growth of the crop, which is equally as good as that provided by the basal fertilizer.

Basal dressing fertilizer is known to be effective in the soil for the first four weeks of application. The low tepary bean yield for the basal only treatment may be attributed to this. By the time the crop was harvested, basal fertilizer applied at planting would have been exhausted. Balanced use of inputs like fertilizers and moisture is essential for improving the harvest index of grain crops [34]. Yields obtained in this study consummate with those obtained elsewhere, estimated to reach 200 to $900 \mathrm{~kg}$ per hectare; variations come as a result of differences in sowing density and rainfall [19].

These results show that the tepary bean is a resilient crop, able to survive in drought climates. This finding is consistent with Gary [28] who reported that the tepary bean is drought and disease resistant, and provides a quick harvest that is high in nutritional value. Therefore, the tepary bean is expected to have significant potential for introduction into semi-arid areas. It has also been reported that, with climate change, droughts would become more frequent and more severe in southern Africa and drought affected areas are projected to increase in extent [35].

Although cowpea yielded the most, tepary beans compared well with common beans at Makoholi (Table 2). This is attributed to tepary beans being one of the most drought resistant legume species in the whole world according to Well [20]. The tepary bean is 


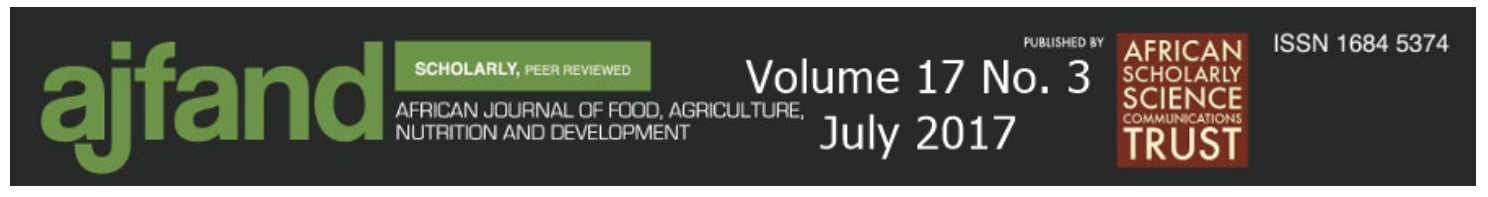

recognized for its resistance to heat, drought and many diseases [28]. It is capable of giving a notable yield with annual precipitation of less than $400 \mathrm{~mm}[36,37,38]$. Compared to common beans, tepary beans have been shown to be superior in combining desirable traits that make the crop well adapted to drought stress [39]. Tepary beans particularly provide hope to smallholder bean farmers affected by climate change in southern Africa as they have naturally evolved with resistance to drought and high temperature conditions [36].

\section{CONCLUSION}

This study shows the importance of climate smart crops and their potential in the food security, nutrition and human health nexus. It is possible that the key to future food and nutrition security may very well lie in the untapped potential of climate smart crops. Therefore, it is imperative that locally adaptable climate smart crops be studied and evaluated for drought tolerance using agronomic techniques and modern techniques such as crop modelling, which allow for rapid evaluation of production scenarios. The combination of water scarcity, climate change and variability and the increasing human population of southern Africa paints a gloomy picture of future food security for a region that already has scarce water resources. In addition to their adaptation to diverse ecological niches, small grain cereal crops and drought tolerant legumes are said to be highly nutritious and in some cases to have medicinal properties. There is, however, limited quantitative information proving some of these claims. Extremely drought tolerant grain legumes such as tepary beans and cowpeas can be grown in the smallholder drought prone farming areas. Most of these legumes are capable of giving a notable yield with annual precipitation of less than $400 \mathrm{~mm}$. The results from this study show that smallholder farmers can grow cowpeas, tepary beans and common beans as drought tolerant leguminous crops for food security. There is, however, need for more research to promote the production and utilization of tepary beans by smallholder farmers in Zimbabwe as a new climate smart crop.

\section{ACKNOWLEDGEMENTS}

The authors acknowledge the National Research Foundation of South Africa through the Research Chair: Agronomy and Rural Development, University of KwaZulu-Natal, for funding this study. 


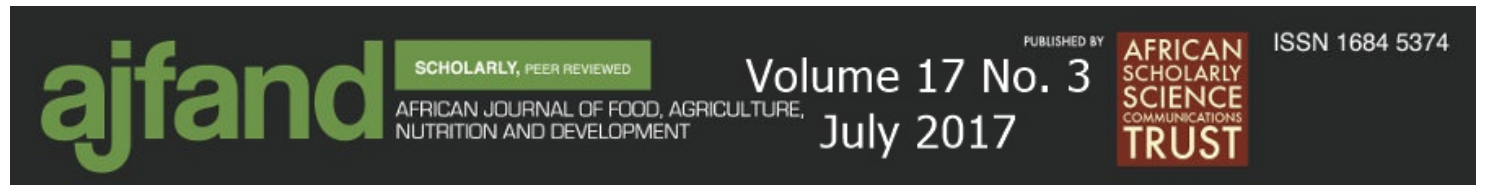

Table 1: Cereal agronomic and yield performance in Masvingo Province, Zimbabwe

\begin{tabular}{lcccc}
\hline Crop & \multicolumn{4}{c}{ Agronomic parameter } \\
\hline & $\begin{array}{c}\text { Day to 50\% } \\
\text { emergence }\end{array}$ & $\begin{array}{c}\text { Days to 50\% tasseling } \\
\text { and flowering }\end{array}$ & $\begin{array}{c}\text { Biomass (dry) } \\
\text { (t/ha) }\end{array}$ & $\begin{array}{c}\text { Grain yield } \\
\text { (kg/ha) }\end{array}$ \\
\hline Maize & $7 \mathrm{a}$ & $59 \mathrm{a}$ & $5.0 \mathrm{a}$ & 0.0 \\
Sorghum & $6 \mathrm{a}$ & $53 \mathrm{a}$ & $1.3 \mathrm{~b}$ & 0.0 \\
Pearl millet & $5 \mathrm{a}$ & $61 \mathrm{a}$ & $1.2 \mathrm{~b}$ & 0.0 \\
Finger millet & 6a & $65 \mathrm{a}$ & $0.7 \mathrm{c}$ & 0.0 \\
\hline
\end{tabular}

Letters refer to significant differences at the $P \leq 0.05$ level

Table 2: A field comparison of pulses agronomic and yield performance in Masvingo Province, Zimbabwe

\begin{tabular}{lccccc}
\hline Crop & \multicolumn{5}{c}{ Agronomic parameter } \\
\hline $\begin{array}{l}\text { Day to 50\% } \\
\text { emergence }\end{array}$ & $\begin{array}{c}\text { Days to 50\% } \\
\text { flowering }\end{array}$ & $\begin{array}{c}\text { Pod yield } \\
(\mathrm{kg} / \mathrm{ha})\end{array}$ & $\begin{array}{c}\text { Biomass (dry) } \\
(\mathrm{kg} / \mathrm{ha})\end{array}$ & $\begin{array}{c}\text { Grain yield } \\
\text { (kg/ha) }\end{array}$ \\
\hline Tepary bean & $5 \mathrm{a}$ & $36 \mathrm{a}$ & $151.1 \mathrm{a}$ & $200.0 \mathrm{a}$ & $245.9 \mathrm{a}$ \\
Cowpea & $4 \mathrm{a}$ & $51 \mathrm{~b}$ & $877.0 \mathrm{~b}$ & $502.2 \mathrm{~b}$ & $568.1 \mathrm{~b}$ \\
Bambara nut & $12 \mathrm{~b}$ & $46 \mathrm{~b}$ & - & $404.4 \mathrm{~b}$ & 0.0 \\
Pigeon pea & $11 \mathrm{~b}$ & $148 \mathrm{c}$ & - & $493.3 \mathrm{~b}$ & 0.0 \\
Common bean & $12 \mathrm{~b}$ & $54 \mathrm{~b}$ & $14.8 \mathrm{c}$ & $51.5 \mathrm{c}$ & $227.0 \mathrm{a}$ \\
Groundnut & $8 \mathrm{~b}$ & $38 \mathrm{a}$ & - & $1,412.6 \mathrm{~d}$ & 0.0 \\
\hline Letters refer to significant differences at the P $\leq 0.05$ level & & &
\end{tabular}




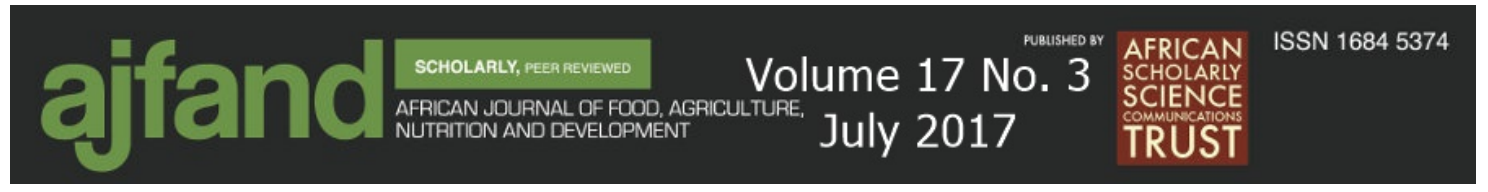

\section{REFERENCES}

1. IRRI. The importance of legumes in cereal cropping systems. Central Knowledge Bank, 2009.

2. Cordain L Cereal Grains: Humanity's Double-Edged Sword. World Rev Nutr Diet. Basel, Karger, 1999; 84:19-73.

3. McKevith B Nutritional Aspects of cereals. British Nutrition Foundation, London, UK, 1985, 111-142.

4. Topping D Cereal complex carbohydrates and their contribution to human health. Journal of Cereal Science, 2007; 46: 220-229.

5. CGIAR. Leveraging legumes to combat poverty, hunger, malnutrition and environmental degradation, 2012.

6. IAC. Realizing the promise and potential of African agriculture. InterAcademy Council, 2004.

7. Kashyapi A, Hage A and DA Kulkarni Impact of climate change on world agriculture: a review. In Impact of Climate Change on Agriculture, n.d. 89 - 93.

8. Brooks N, Anderson S, Ayers J, Burton I and I Tellam Tracking adaptation and measuring development. IIED, 2011.

9. Lobell DB, Burke MB, Tebaldi C, Mastrandrea MD, Falcon WP and RL Naylor Prioritizing Climate Change Adaptation Need for Food Security in 2030. Science, 2008; 319: 607-610.

10. FAO. News Article: 1.02 billion people hungry. Rome, 2009.

11. Turral H, Burke J, Faurès JM and JM Faurés Climate change, water and food security. Rome: Food and Agriculture Organization of the United Nations., 2011, 204.

12. Brassard $\mathbf{J P}$ and $\mathbf{B}$ Singh Impacts of climate change and $\mathrm{CO}_{2}$ increase on agricultural production and adaptation options for Southern Québec, Canada. Mitig. Adapt. Strateg. Glob. Change, 2008; 13: 241-265.

13. Newsham A and D Thomas Agricultural adaptation, local knowledge and livelihoods diversification in North-Central Namibia, 2009. Tyndall Centre for Climate Change Research Working Paper 140.

14. Rurinda J, Mapfumo P, Van Wijk MT, Mtambanengwe F, Rufino MC, Chikowo $\mathbf{R}$ and $\mathbf{K}$ Giller Sources of vulnerability to a variable and changing climate among smallholder households in Zimbabwe: A participatory analysis. Climate Risk Management, 2014; 3: 65-78. 


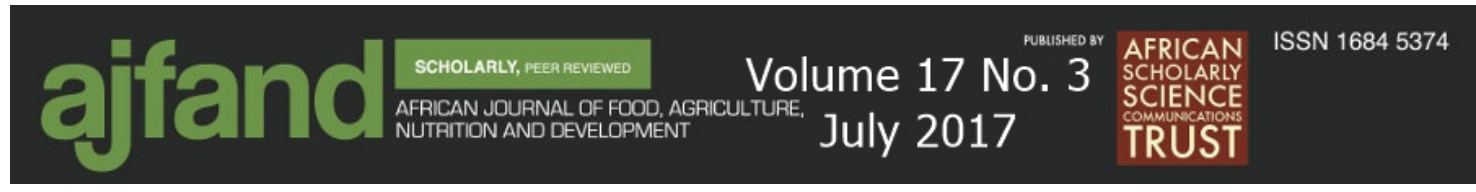

15. Kalanda-Joshua $M$, Ngongondo $\mathbf{C}$, Chipeta $\mathbf{L}$ and $\mathbf{F}$ Mpembeka Integrating indigenous knowledge with conventional science: Enhancing localised climate and weather forecasts in Nessa, Mulanje, Malawi. Physics and Chemistry of the Earth, 2011; 36(14-15): 996-1003.

16. Solh M and M Van Ginkel Drought preparedness and drought mitigation in the developing world's drylands. Weather and Climate Extremes, 2014; 3: 6266.

17. FAO. Success Stories on Climate-Smart Agriculture, 28: 2014.

18. Lal R Food security in a changing climate. Ecohydrology \& Hydrobiology, 2013; 13(1):8-21.

19. Greenfingers J Phaseolus acutifolius: The Amazing Tepary Bean | Colorado Plateau Gardening and Horticulture, 2014.

20. Weil A Cooking With Legumes: Tepary Beans - Dr. Weil's Healthy Kitchen, 2015.

21. Hart A Defeat Diabetes Month in April with tepary beans - Sacramento vegan, 2012.

22. Bogler D Descriptions and articles about the Tepary Bean (Phaseolus acutifolius as classified by Integrated Taxonomic Information System (ITIS)) Encyclopedia of Life, 2014.

23. McCarthy JJ Climate Change 2001: Impacts, Adaptation, and Vulnerability: Contribution of Working Group II to the Third Assessment Report of the Intergovernmental Panel on Climate Change. Cambridge University Press, 2001.

24. Adger WN and $\mathbf{J}$ Barnett Four reasons for concern about adaptation to climate change, Environment and Planning A, 2009; 41(12): 2800-2805.

25. Isaiah Esipisu Climate-smart Kenyan crop hits a setback - hungry birds, Thompson Reuters Foundation News, 2013. http://news.trust.org//item/20130807112810-q5vw8/ Accessed 16th June 2015.

26. Kassie BT, Hengsdijk H, Rötter R, Kahiluoto H, Asseng $S$ and $M$ Van Ittersum Adapting to climate variability and change: experiences from cerealbased farming in the Central Rift and Kobo Valleys, Ethiopia. Environmental Management, 2013; 52(5): 1115-1131.

27. Kandji ST, Verchot $\mathbf{L}$ and $\mathbf{J}$ Mackensen Climate change and variability in the Sahel Region: impacts and adaptation strategies in the agricultural sector. Environment, 2006; 254: 20 - 48. 


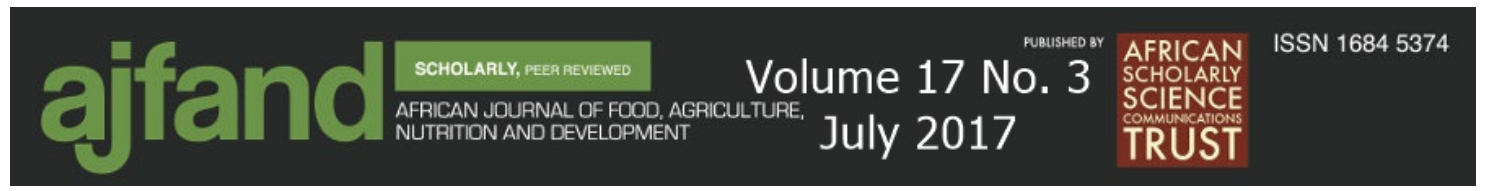

28. Gary N Tepary bean crop ecology. Papago Indian Reservation, Arizona, USA, 2010. https://naldc.nal.usda.gov/download/IND43777888/PDF. Accessed 16th June 2015.

29. Chivenge P, Mabhaudhi T, Modi A and P Mafongoya The Potential Role of Neglected and Underutilised Crop Species as Future Crops under Water Scarce Conditions in Sub-Saharan Africa. International Journal of Environmental Research and Public Health, 2015; 12(6): 5685-5711.

30. Jost $\mathbf{C}$, Kyazze $\mathbf{F}$, Naab $\mathbf{J}$, Neelormi $\mathbf{S}$, Kinyangi $\mathbf{J}$, Zougmore $\mathbf{R}$ and $\mathbf{P}$ Kristjanson Understanding gender dimensions of agriculture and climate change in smallholder farming communities. Climate and Development, 2015, $1-12$.

31. González-Quijada MR, Alanís-Guzman MG and SO Serna-Saldivar Ebony (Pitecellobium flexicaule Benth) and proteins fractionation, solubilization, characterization and production of an isolate. Archivos Latinoamericanos de Nutrición, 2003; 53(1): 84-89.

32. Tinsley A Tepary beans (Phaseolus acutifolius var. latifolius): a potential food source for African and Middle Eastern cultures - Springer, 1985; 35(2): 87-101.

33. Shisanya $\mathbf{C}$ The effect of Nitrogen Fertilizer and Management on Nodulation and Growth of Legumes, 1998.

34. Ahmad R Improving crop harvest index - Newspaper - DAWN.COM, 2007.

35. Patel R Grassroots voices: What does food sovereignty look like? The Journal of Peasant Studies, 2009; 36(3): 663-706.

36. Andrews D Tepary Bean, Phaseolus acutifolius. Arizona Wild Flowers. Pictures, Photos, Images, Descriptions, Information, Reviews, 2014.

37. Constantino L Mediterranean Cooking in Alaska: Ingredient: Tepary Beans with Recipe for Tepary Bean and Vegetable Stew, 2009.

38. Jiri O and PL Mafongoya Tepary Bean: A Climate Smart Crop for Food and Nutritional Security. Journal of Nutrition \& Food Sciences, 2016; 6 (3): 490. doi: $10.4172 / 2155-9600.1000490$

39. Stephens JM Bean, Tepary? Phaseolus acutifolius A. Gray, Institute of Food and Agricultural Sciences (IFAS), University of Florida, USA, 2013. http://edis.ifas.ufl.edu/mv025. Accessed 24th September 2015. 